subtle and close, but the two elements can be easily separated. It avails nothing to say that until the thought is placed under a concept, it is not a thought. This is a mere question of definition, not of actual fact.

I would point out one other consideration. If Prof. Müller's theory were true for all kinds of thinking, development would be impossible. If man could not think without language, and could not have language without thinking, he would never have had either, except by a miracle. And scientific men will not accept the alternative. We can conceive shadowy thoughts gradually shaping to themselves a language for expression, and we can understand how each would improve the other, until by constant interaction, a higher process of thought was introduced. But we cannot conceive the sudden appearance of the faculty of abstraction together with its ready-made signs or words.

I have often wished that Prof. Muiller would state distinctly how his theory accounts for the very first beginnings of language. I have not been able to discover any explanation of this point in his "Lectures on the Science of Language."

Clapham, June 6.

Arthur EbBels.

As poets have extraordinary inklings and aperçus on the most abstruse scientific questions, Wordsworth's opinion on this matter (quoted by De Quincy) is worth considering: Language is not the "dress" of thought, it is the "incarnation." This is Shelley's aperçu of Darwinism. Man exists " but in the future and the past; being, not what he is, but what he has been and shall be."

How to "distil working ideas from the obscurest poems"to use Lord Acton's words-is one of the secrets of genius.

A. GKENFELL.

THE interesting discussion betiveen Mr. Francis Galton and Prof. Max Müller on this subject will doubtless raise many questions in the minds of those who have paid some attention to the habits of animals. I have been asking myself whether, if Prof. Max Müller is right in his conclusion- "Of course we all admit that without a name we cannot really know anything" (an utterable name, I presume), and "one fact remains, animals have no language "-animals must not, therefore, be held by him incapable of knowing anything. This would bring us to the question whether animals know in the same manner as men, or in some other manner which men do not understand. Now, I think-at least it is as strong a conviction as I am capable of entertaining-that animals not only know, but deal with the materials of knowledge-facts-in a manner quite indistinguishable from the manner in which I mentally handle them myself. Thus, I place an animal in circumstances which are quite unfamiliar to it, and from which it is urgently pressed to escape. There are two, or perhaps three, courses open to it ; one being, to my mind, patently the most advantageous. It tries all of them, and selects that which I should have chosen myself, though it is much longer in coming to its conclusion. Here the animal has the same facts as the man to deal with, and, after consideration and examination, its judgment precisely corresponds with the man's. I cannot, then, find it possible to deny that the mental operations are identical in kind; but that they are not so in degree can be demonstrated by my importing into the situation an element foreign to the experience of the animal, when its failure is certain. It makes no difference whether the animal is under stress, or acting voluntarily. It may frequently be found to choose the method which most recommends itself to the man's judgment. Every student of animals is familiar with numbers of such cases. Indeed they are constantly being recorded in the columns of NATURE, and abound in all accepted works on animal intelligence. I am quite prepared to admit that where there are two or more courses open to it the animal will occasionally select that which presents the greatest difficulties, and labour most assiduously to overcome them, sometimes trying the remaining courses and returning to that wh ch it first chose. Darwin gives a good example of the honey-bee ("Origin of Species," p. 225, edition 1872). But no one will be surprised at imperfect judgment or vacillation of will in an animal, when such are common among men.

Prof. Max Müller lays down the very distinct proposition that "animals have no language." I suppose utterable language is meant. Is this so ? That their sign-language is both extensive and exact (and even understood to some extent as between widely different species) most naturalists, I apprehend, will entertain no doubt. But has any species an utterable language? What is to be the test of this? First there is the whole gamut of vocal expressions-which even we understand-conveying the ideas of pain, pleasure, anger, warning. What sportsman who has stalked extremely shy animals does not know the moment a bird or animal utters a certain note that he is discovered? If Prof. Max Müller will not admit this to be language, I, for one, must ask him what it is. It conveys to others a distinct idea, in general if not in special terms, and seems to me quite equivalent to "Oh, dear!" "This is nice" (expressed, I believe, in some African language by the reduplicated form num-ñum, the letter $n$ having the same value as in the Spanish mañana), "Leave off, "Look out," "Come here," \&c. Those who have heard animals calling to one another, particularly at night, and have carefully noted the modulations of their voices (why should there be modulations unless they have a definite value), will find it very hard to accept Prof. Max Muiller's conclusion that "animals have no language." Every female mammal endowed with any kind of voice has the power of saying "Come here, my child," and it is an interesting fact beyond question that the knowledge of this call is feebly or not at all inherited, but must be impressed upon the young individual by experience. Further, the young brought up by an alien foster-mother pay no attention to the "Come here, my child," of the alien species. The clucking of the hen meets with no response from the ducklings she has reared, even when she paces frantically by the side of the pond imploring them not to commit suicide. But let us creep up under the banks of a sedgy pool at about this time of year. There swims a wild duck surrounded by her brood, dashing here and there at the rising Phryganida. Now let the frightful face of man peer through the sedges. A sharp "quack" from the duck, and her brood dive like stones, or plunge into the reeds. She, at least, knows what to say to them.

The already inordinate length of this letter precludes me from offering any instances of the communication of specific intelligence by means of the vocal organs of animals. I think it probable that we far under-rate the vocabulary of animals from deficient attention - and, I speak for myself, stupidity. Possibly Prof. Max Miiller has not yet examined "Sally," the black chimpanzee. If not, he would surely be much interested. She is by no means garrulous, but, in spite of her poor vocal capacity, if he should still consider that she "cannot really know anything" on that account, I must have completely misinterpreted his letter to Mr. Galton.

Watford, June 3 .

ARTHUR NiCOLS.

\section{Two Friends}

THE remarks on the reasoning powers of animals (dogs in particular) given in your issue of June 9 ( $p .124)$ induce me to relate an experience of my own. We possess a dog and a cat, both males, the former called Griffon here, much like a Skye terrier, the latter a splendid animal (a cross of the Angora). These two animals are bound to each other by the closest friendship, which began thus:- The dog came to us two years ago, quite a pup-about three months old. Soon after a small, wretched, half-starved kitten arrived at our door asking hospitality. The dog at once adopted it, let it eat out of the same dish, let it sleep on the same mat (and continues to do so still), in fact took entire charge of it. A black cat, a very vicious creature, and seemingly wild, haunted our garden, to the great destruction of birds' nests and to the excessive terror of the kitten. As the dog grew, it became the kitten's protector against the black cat, and has been so now for two years. If it was indoors and heard a cry of distress from our cat, you could not hold it from flying wildly to its rescue, forcing someone to open the door, or darting through a window. It has done this so long, and with such effect, that the black cat scarcely dares show its face in the garden, as the dog invariably attacks it with fury and drives it away, following it along the road to see if it is quite gone. I do not know if you will think this worthy of insertion, but $I$ think it curious, and I can vouch for its truth. M. C. La Tour de Peily, June I3.

\section{The Use of Flowers by Birds.}

As a curious incident enacted by sparrows has just come under my notice, which possesses some added interest in connexion with the two occurrences recorded by your correspondent 